\title{
Német-Ausztria születése: 1918. november 12.
}

\author{
Tóth Imre*
}

\begin{abstract}
The birth of German-Austria: November 12, 1918. On this November day, politicians and offices of the Austrian state that was being formed since mid-October made their decision on the new provisional constitution. As a result, German-Austria chose republic as the form of state. Therefore, the date is considered to be the birthday of the republic of Austria. In our paper, we present the November 12 events in Vienna and the decisions of the Austrian politicians, thus sketching the birth of German-Austria.
\end{abstract}

Keywords: Great War (1914-1918), history of Central-Europe, birth of the first Austrian Republic, Vienna

1918. november 12-én hideg és nyirkos időre ébredtek Bécs lakói. A város számos kerületében a szociáldemokrata párt szervezetei tartottak gyüléseket. Ezeken mindenekelőtt az előző nap elhunyt Viktor Adlerről emlékeztek meg. Adler, a szociáldemokrata párt alapítója, és Német-Ausztria külügyi államtitkára váratlanul halt meg szívrohamban. A párt vezetői felszólították a gyüléseken megjelent munkásságot, hogy vonuljanak a parlament épülete elé, a köztársaság ünnepélyes kikiáltásának üdvözlésére. Hozzájuk hasonlóan más szervezetek is a parlament elé szólították szimpatizánsaikat. Délután háromtól hatig leálltak a villamosok a városban, a vasutasok egy órán át szüneteltették a munkát. Az élelmiszerboltok délig zavartalanul müködtek, délután azonban bezártak. ${ }^{1}$

A ,kezdet“ iránti igény Ausztriában is éppoly szükséglet, mint más helyeken, nem csoda hát, ha vita folyik arról, hogy melyik nap az Osztrák Köztársaság születésnapja. Voltak és vannak is olyanok, akik 1918. október 30-át tartják annak, amikor az új kvázi végrehajtó hatalom létrejött. A nemzeti közemlékezet azonban nem vállalta a napot, aminek az a magyarázata, hogy október 30-án, és utána napokig Ausztria államformája még császárság volt, ráadásul a régi kormány is hivatalban maradt. Való igaz, hogy mégis volt olyan kísérlet, mely az október végi mozzanat a szakralizálását célozta. Karl Renner (aki az új kormánynak a feje, államkancellár lett) 1947-ben azzal bízta meg Max Frey festőmüvészt, hogy az 1918. október 30-án történt eseményeket örökítse meg a köztársaság múzeuma számára. A kép el is készült, de született egy másik is, mely ma a parlament épületében látható. Rodolf Konopa tablóján november 12. történései jelennek meg.

\footnotetext{
* Intézmény: Soproni Egyetem

Email: totim2@gmail.com

${ }^{1}$ Illustrierte Kronen Zeitung, 1918. november 12. 3-4. old.
} 
Az alkotmányos átalakulás valóban inkább köthető november 12-hez (némileg kompromisszumos perspektívából november 11-12-hez), amikor a formálódó állam ideiglenes szervei végérvényesen és visszavonhatatlanul döntöttek az új, ideiglenes alkotmányról, és Ausztria (Német-Ausztria) köztársasági államformát választott. Ezt emelte kánonjába a későbbi Ausztria. 1919-ben a nemzetgyülés ezt a napot nyilvánította hivatalos ünneppé, ezt örökíti meg a parlament épületétől nem messze álló államalapítási emlékmü, és Bécs körútja, a Ring parlament elötti szakasza is a November 12. körút nevet viselte egészen 1934-ig. Messze nem véletlenül.

Az előzőekkel diametrálisan szemben álló politikai világlátás, az 1934. május 1-től konstituálódott hivatásrendi állam is hasonló jelentőséget tulajdonított a napnak azzal, hogy éppen 1918. november 12-e emlékét próbálta meg kiiktatni a közemlékezetből. Indokolta ezt pedig azzal, hogy az inkriminált nap volt az, mely Ausztriát „sírba tette“.2 A nemzeti önreprezentáció csak a második világháború után talált vissza november 12. emlékéhez.

Az események közvetlen előzményei legalább október első napjaira mennek vissza, amikor bizottság alakult a német nemzeti pártok képviselőiből, amely, mint pártok feletti frakció szervezte meg önmagát az osztrák képviselőházban. Ez a bizottság állt elő a tervvel, hogy a Reichsrat német tagjaiból ideiglenes nemzetgyülést hívjanak egybe. Október 21-re az alsó-ausztriai tartományi gyülés Herrengasse 13. szám alatti üléstermében meg is tartotta első ülését Német-Ausztria Ideiglenes Nemzetgyülése. ${ }^{3}$ Ez volt az első hivatalos lépés a későbbi osztrák köztársaság megalakulásának folyamatában.

$\mathrm{Az}$, hogy a birodalom német választókerületeinek képviselői önálló útra léptek, és a Monarchia minden nemzetiségét megelőzve, október 21-én megalakítottak az önálló Német-Ausztria ideiglenes nemzetgyülését, az I. Károly-féle konföderációs átalakítási kísérlet kudarcát támasztotta alá.

Az Ideiglenes Nemzetgyülés második, október 30-i ülésén hatályon kívül helyezte az Osztrák Birodalmi Tanácsban képviselt királyságok és tartományok előtti miniszteri felelősségről szóló,1867. július 25-i törvényt, és a Reichsrat elnökeiből és húsz választott tagból végrehajtótanácsot hoztak létre, mely az ország lakossága és a külföld előtt az államot képviselte. A német nemzeti Franz Dinghofer, a keresztényszocialista Jodok Fink és a szociáldemokrata Karl Seitz vezetésével mủködő testület gyakorlatilag a végrehajtó hatalom irányítását vette át. ${ }^{4}$

A kormányfunkciókat ellátó testület mellett október 27-ig még hivatalban volt a császár által kinevezett Hussarek-kormány, majd október 28-tól november 11-ig a szintén az I. Károly megbízásából hivatalba lépő Heinrich Lammasch vezette kabinet. A nemzetgyülés tagjai által nagy óvatossággal papírra vetett szabályozás átmeneti volt, mivel a törvényhozók nem akartak nyílt konfliktusba kerülni a császárral és egyenesen szembemenni az addig hatályos alkotmánnyal. Az óvatosság ellenére, és annak dacára, hogy a határozat nem deklarálta a köztársaságot, a képviselők megtették monarchikusból a köztársasági államforma felé való átmenet első lépését. Addigra azonban végérvényessé vált: a többi nemzetiség által választott nemzeti tanácsok Bécstöl független államokat kívánnak létrehozni. ${ }^{5}$ Amikor november 3-án Páduában az Osztrák-Magyar Monarchia

\footnotetext{
${ }^{2}$ Lásd erről: Rauchensteiner, Manfried: Unter Beobachtung. Österreich seit 1918: Böhlau Verlag, Wien, 2017. 27. old.

${ }^{3}$ A német képviselők Nemzetgyülésének első (alakuló) ülése. 1918. október 21. Stenographische Protokolle über die Sitzugen der provisorischen Nationalversammlung für Deutschösterreichs 1918 und 1919. (Sten.Prot) Bd. 1. 5. és Reichspost, 1918. október 22. 1. old.

${ }^{4}$ Németausztria Ideiglenes Nemzetgyülésének határozata az államhatalom alapvető berendezkedéséröl, 1918. október 30. 4-6. §.

${ }^{5}$ Bővebben lásd Gulyás László-Szávai Ferenc 2018, 46-51.
} 
nevében aláírták a fegyverszüneti megállapodást, az osztrák-magyar állam de facto már nem létezett.

Ilyen előzmények után az ideiglenes nemzetgyülésnek határozott cezúrát kellett vonni a korábbi és az új Ausztria közé. Ezt segítette az a tény, hogy Károly november 11én lemondott az államügyekben való részvételröl, és ezzel elöre elismerte az államformáról megszülető majdani döntést. Nyilatkozatát szó szerint idézzük: „,Trónra lépésemtöl kezdve szakadatlanul azon fáradoztam, hogy népeimet a háború borzalmaiból kivezessem, abból a háborúból, melynek kirobbánásában semminemü felelösség nem terhel. Nem haboztam az alkotmányosságot helyreállitani, és szabaddá tettem népeim önálló állami fejlödése felé vezetö útját. Az irántuk érzett változhatatlan szeretetem nem engedi, hogy személyem szabad kibontakozásuk útjába álljon. Elözetesen elfogadok Német-Ausztria jövőbeli államreformjával kapcsolatos minden döntést. A nép képviselöi útján átvette a kormányzást. Az államügyekben való részvételemröl ezennel lemondok, egyidejüleg felmentem hivatala alól kormányomat. Német-Ausztria népe egyetértésben és békében megteremtheti és megszilárdithatja új állami rendjét. Népeim boldogulása a kezdetetktöl fogva legforróbb kívánságom volt. Csak a belsö béke képes e háború sebeit begyógyítani. Kelt Bécsben, 1918. november 11-én. Károly”.

A változás mindenki számára látható jeleként a Hofburgot délután minden oldalról, teljes egészében lezárták. Az épület előtt a biztonsági örszemélyzet posztolt, az udvaron azonban már a Volkswehr katonái és tisztjei álltak őrt. Este hét órakor hét kocsiból álló konvoj sorakozott fel a schönbrunni kastély udvarán. Az első kettőben a kísérőszemélyzet, a harmadikban Károly császár - pontosabban Habsburg Károly foglalt helyet a családjával, hogy elhagyja a schönbrunni palotát és a Morvaországban található eckartsaui vadászkastélyába távozzon. ${ }^{6}$

Az ideiglenes nemzetgyülés képviselői másnap, november 12-én szintén elhagyták addigi helyüket, a Herrengassén álló üléstermet és átköltöztek a Ringen található parlament épületébe. Az ülést délután három órára hirdették meg. A törvényhozás összetétele nem tükrözte a közben zajló utcai hangulatot és az épület falain kívüli mozgalmak erőviszonyait. 208 tagjából 65 volt keresztényszocialista, 37 szociáldemokrata és 106 nagynémet. A képviselőket aznap egy 11 cikkelyböl álló törvényjavaslat várta. Ezt az államtanács fogalmazta meg az előző nap délelőtti ülésén. A cikkelyek közül a legelső és legfontosabb az állam-és kormányformáról való döntés volt. A második a törvényhozás hivatalos közlönyének létrehozásáról, a harmadik szintén húsbavágó problémáról, az államterület kijelöléséről szólt. Alaptörvényt készültek elfogadni az állampolgárságról, a bírói hatalomról és a tartományi kormányok és gyülések létrehozásáról. ${ }^{7}$ Renner kancellár, illetve az államtanács tagjai, tehát úgy döntöttek, hogy államforma kérdésében nem halogatják a döntést, és nem várják meg alkotmányozó nemzetgyülés összehívását sem, amint azt eredetileg tervezték.

Az ideiglenes alkotmányt Renner terjesztette a Ház elé. A javaslatot egyhangúan elfogadták. Német-Ausztria államformája demokratikus köztársaság lett. A törvény második cikkelyével a nemzetgyülés az új államot a Német Köztársaság részének nyilvánította. Az alkotmányozó nemzetgyülés összehívásáig valamennyi jog, mely a császárt megillette az államtanácsra szállt. (Utóbbinak három elnöke volt a három vezető pártból, rajtuk kívül 20 tag alkotta a testületet.) A császári ház által hozott törvényeket hatályon kívül helyezték, a k. u. k. minisztériumokat feloszlatták, a katonákat, tisztviselöket, hivatalnokokat pedig felmentették az uralkodónak tett esküjük alól. A császár, illetve a császári ház tagjainak minden kiváltságát eltörölték és a politikai előjogokat is megszüntették. A koronajavak átvételéröl egy későbbi törvényben

\footnotetext{
${ }^{6}$ Illustrierte Kronen Zeitung, 1918. november 12. 3-4.old.

${ }^{7}$ Reichspost, 1918. november 12. 2. old.
} 
intézkedtek. A törvény 1919 januárjára alkotmányozó nemzetgyülés összehívását kezdeményezte. A törvényhatósági választásokat három hónapon belül kellett megtartani. Mindaddig helyükön maradtak a régi helyhatóságok, de a törvény úgy intézkedett, hogy a testületeket ,arányosan” ki kell egészíteni a munkásság képviselőivel. ${ }^{8}$ Mindezzel megszünt minden jogi értelemben vett folytatólagosság a régi és az új Ausztria között, Német-Ausztria november 12-én háromnegyed négykor államjogi értelemben létező entitássá vált.

A jelentőségteljes átalakulás főszereplői meglehetősen mértéktartóak voltak. Karl Renner kormányfő a nemzetgyülési ülés idején találkozóra várta az osztrák császárság utolsó miniszterelnökét, Heinrich Lammasch-t, hogy átvegye tőle Károly császár lemondó nyilatkozatát. Renner türelmetlenül rontott ki a parlament ülésterméből a várva várt dokumentumért, de Amalie Pölzer, a titkárnője visszaküldte azzal, hogy Lammasch még nem érkezett meg. Miután ez a jelenet többször megismétlődött, Renner kilépett az előszobába, ahol a sarokban ott üldögélt a császár utolsó kormányának feje, és türelmesen várakozott a sorára. Pölzer kisasszony úgy hitte, egy kérelmezővel van dolga. ${ }^{9}$ A történet jól illusztrálja azt az átmenetet, amely a Habsburg Ausztriából a köztársasági NémetAusztriába - leszámítva két kisebb incidenst - minden különösebb forradalmi megrázkódtatás nélkül lezajlott.

Ahogy az ülésnek vége lett, rövidel négy óra elött a kormány tagjai és a képviselők az államtanács tagjainak vezetésével, az átriumon keresztül a parlament homlokzati oszlopcsarnoka alá vonultak, ahol az államtanács elnöke, Franz Dinghofer felolvasta a frissiben elfogadott alaptörvény cikkelyeit. Az 1883-ra felépült, antik görög templomot formázó törvényhozási palota rámpájára ideiglenes tribünt ácsoltak a jelentősnek ígérkező esemény méltó megünneplésére. A készülődés nem is volt hiábavaló. Az előző napi felhívásoknak köszönhetően az épület elött nagyjából 150000 ember jelent meg. Néhányan a fákra és a parlament elötti szobrok posztamenseire is felmásztak. Természetesen mindenki a köztársaság kikiáltását várta. Legnagyobb számban a szociáldemokrata párt hívei vonultak fel, akik a Schwarzenbergplatzon gyülekeztek, hogy aztán a már a korábbi évtizedekben Via Triumphalissá átnemesült Ringre érkezve meghallgassák és megéljenezzék a nagy bejelentést, majd utána a Votivkirche előtti téren oszlassák fel a tüntetésüket. A hangulatot főleg ők uralták. A parlament elött sokasodó tömeg is ,éljen a szocialista köztársaság“ feliratú plakátra szegezhette a tekintetét. A nagynémetek fél háromra hívták támogatóikat a közeli Schauflergasséra. Nekik csak az ideiglenesen lezárt Volksgarten mellett kellett elsétálniuk és már ott is voltak a parlament előtt, az egyébként II./I. Ferencről császárról elnevezett Franzensringen. A sokaságban először munkásmozgalmi dalokat lehetett hallani, amire a német nacionalisták a die Wacht am Rhein kezdetü dallal, a német császárság nem hivatalos himnuszával válaszoltak. A feszültség percek alatt tapinthatóvá vált.

Amint az hasonló jelentőségü események idején lenni szokott, az államtanács általános alkoholtilalmat rendelt el Német-Ausztria teljes területére. ${ }^{10}$ Egy kisebb, de erőszakos csoport így tiszta fejjel készült rá, hogy az ünnepélyesnek ígérkező eseményt a radikális baloldal demonstrációjává alakítsa. A hivatalos beszédek közben a sárga-fekete birodalmi zászló helyére éppen felvonták a köztársaság jelképét a piros-fehér piros sávos lobogót, amikor a radikális Vörös Gárda néhány közelben álló tagja lerángatta a zászlót, hogy középső fehér sávját kiszakítsa belöle és vörös foszlányokat húzza ismét a rúdra. Az átmeneti zavar után Dinghofer átadta a szónoki pódiumot Rennernek, aki az államreform lényegét és a

\footnotetext{
${ }^{8}$ Törvény Német-Ausztria állam-és kormányformájáról, 1918. november 12. Staatsgesetzblatt für den Staat Deutschösterreich, 1918. Nr. 5.

${ }^{9}$ Berczeller, Richard-Leser, Norbert: Mit Österreich verbunden. Wien München, 1975, Volk und Jugend, $147-$ 148.

${ }^{10}$ Salzburger Chronik, 1918. November 12. 3. o., Neue Freie Presse, 1918. November 13. 2. old.
} 
nemzetgyülés proklamációját ismertette. Ennek egyik legfontosabb eleme - a már említetteken kívül - a nők választójogának biztosítása volt. A proklamáció, hasonlóan több kolumnista akkoriban megjelent cikkéhez, az 1848-as alkotmányos periódushoz füződő kontinuitást hangsúlyozta. A harmadik felszólaló Karl Seitz beszéde után nagyjából egy tucatnyi radikális megpróbált benyomulni a parlament épületébe. Megfoghatatlan, ki és miért használt fegyvert, de tény, hogy a téren lövések dörrentek. Az egyik eltévedt golyó a kancellária sajtófönökét, Dr. Brügelt érte, aki súlyosan megsérült. A felfordulásban a vörös gárdisták azt hitték, hogy a parlamentböl rájuk céloznak, mire maguk is lövöldözni kezdtek. Végül megegyeztek a rendőrség embereivel, hogy a lövésnek hitt zaj egy lehulló épületelemtől származott. Ez feltehetően mindenki számára elfogadható kompromisszum volt. A minden jel szerint megkönnyebbült Brandl rendörkapitány szerint legalábbis a komunista gárdisták azt beszélték, még nem jött el az ô idejük, és szépen hazamentek. ${ }^{11}$ A nyugalom negyed hat körül helyreállt ugyan, de a tumultus közben több mint harmincan megsérültek, és két embert, egy felnőttet és egy gyermeket halálratapostak. A szomorú eseményekre golyónyomok emlékeztettek a parlament márványfrízein. A Vörös Gárda egyébként annak az író, újságíró Egon Erwin Kischnek a felügyelete alatt állt, aki egyszersmind a forradalmi szocialisták, azaz az osztrák kommunisták egyik vezetője is volt. A parlament elötti incidenssel csaknem egy időben katonái elfoglalták a Monarchia vezető lapja, a Neue Freie Presse szerkesztőségét, ahol egyébként tulajdon öccse is dolgozott. (Miután a szerkesztőség tagjait az utcára zavarták, Paul Kisch így kiáltott idősebb testvérére: Egonek, Egonek, das schreibe ich der Mama ${ }^{12}$ A lap aznap este különszámmal jelentkezett, melyben cáfolták, hogy Vörös Gárdának köze lett volna a lövöldözéshez, a munkásokat szervezkedésre, munkás- és katonatanácsok megalakítására hívta fel. ${ }^{13}$ A szerkesztőség elfoglalása sovány eredményt hozó kísérlete volt az osztrák kommunistáknak a szocialista köztársaság, azaz egy német mintájú tanácsköztársaság kikiáltására. Franz Werfel, a párt egyik vezetője néhány nappal korábban már tartott ugyan egy gyújtóhangú beszédet a Bécsi Bankszövetség épülete előtt, ám akkor még gyengének ítélte saját erejüket. De nem sokára üt az óra - dörögte akkor Werfel, akinek párttársai és szimpatizánsai november 12-én nem ugyanazt a kronométert nézték, mint a társadalom többsége. Noha a puccsisták a szerkesztőség ablakában géppuskát állítottak fel, a szemközti Beethovenparkot és Kollowratringet pedig a hozzájuk hü katonák ellenőrizték, és onnan senkit se be, se ki nem engedtek, az államtanács gyorsan és hatékonyan intézkedett, és a gárdistákat elzavarta.

Renner még aznap nyilatkozott a sajtónak arról, hogy miért volt szükség éppen most a köztársaság kikiáltására. A sorsdöntő órában határozott vonalat kívántak húzni a múlt és a jövő közé, mert a népellenes katonai vezetés, a nagyhatalmú abszolutista bürokrácia ideje lejárt - mondta. Renner mondanivalója azonban a területi kérdésekre hegyezödött ki. Új demokratikus köztársaságunk - folytatta - szembesíti az antant katonai vezetőit és diplomatáit azzal a kérdéssel: komolyan gondolják-e, hogy a francia és az angol munkásság elnézi friss vívmányaink eltaposását? Területeinket a szláv államok között szétosszák, és bennünket koldusbotra juttassanak? ${ }^{14}$ Rennernek persze jól kellett tudnia, hogy az antant nemigen fog másra nézni, mint saját érdekeire, mely részben (de csak részben) egybeesett háborús mellékgyőztesek - többek között a csehek - érdekeivel. Az önállóságot kimondó határozat - éppen úgy, ahogy azt a szociáldemokraták korábban is gondolták előremenekülés volt annak érdekében, hogy a leendö önálló német-osztrák állam kereteit és államterületét mielöbb önmaga tudja kijelölni. Az államtanács kidolgozott egy elaborátumot,

\footnotetext{
${ }^{11}$ Idézi: http://ww1.habsburger.net/de/kapitel/der-12-november-1918. Letöltés ideje: 2018. 06. 20.

12 Egon, Egon, ezt megírom a mamának. Austria-Forum. Das Wissennetz aus Österreich. https://austria-forum.org/af/AustriaWiki/Egon_Erwin_Kisch. Letöltés ideje: 2018. 06. 20.

${ }^{13}$ Neue Freie Presse. Sonder-Ausgabe, 1918. november 12. 6 Uhr Abends és 8 Uhr Abends.

${ }^{14}$ Illustrierte Kronen Zeitung, 1918. November 12. 3-4. old.
} 
mely az új állam határairól és területéről intézkedett. A november 12-i nemzetgyülési ülésen született államnyilatkozat ennek megfelelően már magában foglalta a Birodalmi Tanácsban képviselt országok és tartományok zárt német népterületeinek teljességét. Németausztria részévé nyilvánították az osztrák hercegség területét a cseh és morva és szudétavidéki német területekkel és az osztrák örökös tartományokkal egyetemben A deklaráció kimondta, hogy a csehek és a lengyelek által egyaránt igényelt Szilézia és Kelet-Morvaország gazdaságilag egy egységet képez, ezért a Német-Ausztria kormánya a béketárgyalások során a három állam között kialakítandó politikai egység koncepcióját kívánja képviselni. A nyilatkozatba belefoglalták a Magyar Korona országainak területén fekvő, Német-Ausztriával határos, zárt német településterületre vonatkozó igényeket is. Az Osztrák-Magyar Monarchia területén létrejövő új nemzetállamok területén található, németek által lakott városokat és községeket a népközösség és a több évszázados birodalmi együttélés miatt saját érdekterületté nyilvánították. ${ }^{15}$

Mint ahogy az osztrák szimbolikus politikában november 12. kanonizálása, úgy a reál-, illetve hatalmi politikában a területi igények beváltása sem hozott egyértelmü eredményt. A kettő közül azonban minden kétséget kizáróan az első vált a sikeresebb, ma is élö projektummá.

\section{Felhasznált irodalom}

Az Ideiglenes Nemzetgyülés második ülésének melléklete. 3. Sten.Prot. Bd.1. 23-27. Ill. Államnyilatkozat Németausztria területéről, határairól és kapcsolatairól. Melléklet. 29-30.

Berczeller, Richard-Leser, Norbert 1975, Mit Österreich verbunden. Wien München. Volk und Jugend. Rauchensteiner, Manfried 2017, Unter Beobachtung. Österreich seit 1918: Böhlau Verlag, Wien, 2017. 27. old.

Gulyás László-Szávai Ferenc 2018, Közép-Európa és Wilson 14 pontja. BBC History 2018/október, 46-51. old.

http://ww1.habsburger.net/de/kapitel/der-12-november-1918. Letöltés ideje: 2018. 06. 20. https://austria-forum.org/af/AustriaWiki/Egon_Erwin_Kisch. Letöltés ideje: 2018. 06. 20.

Illustrierte Kronen Zeitung, 1918. november 12.

Neue Freie Presse, 1918. November 13.

Reichspost, 1918. november 12.

Salzburger Chronik, 1918. November 12.

Staatsgesetzblatt für den Staat Deutschösterreich, 1918. Nr. 5.

Stenographische Protokolle über die Sitzugen der provisorischen Nationalversammlung für Deutschösterreichs 1918 und 1919. (Sten.Prot) Bd. 1. 5. és Reichspost, 1918. október 22.

A müre a Creative Commons 4.0 standard licenc alábbi típusa vonatkozik: CC-BY-NC-ND-4.0.

\section{(cc) BY-NC-ND}

\footnotetext{
${ }^{15}$ Az Ideiglenes Nemzetgyülés második ülésének melléklete. 3. Sten.Prot. Bd.1. 23-27. Ill. Államnyilatkozat Németausztria területéről, határairól és kapcsolatairól. Melléklet. 29-30.
} 